\title{
Analytic Assessment of General Aviation Security Issues in the Post-9/11 Environment: Implications for the Small Aircraft Transportation System
}

\author{
Todd A. Bonkiewicz and Brent D. Bowen \\ University of Nebraska at Omaha
}

\begin{abstract}
Until recently, security as a whole was often a low priority in the aviation regulatory environment. In the aftermath of the terrorist attacks of last summer, general aviation came under immediate scrutiny; concomitant to this, it became evident that security was lacking at airports of all sizes and levels of service. These developments created an unforeseen challenge for the Small Aircraft Transportation System (SATS), a new generation of advanced small aircraft and supporting infrastructure designed to provide service to people underserved by current airline route networks. This article reports on policyoriented research - conducted via a meta-analytic process - that analyzes the obstacles facing SATS in the post-September 11 security environment.
\end{abstract}

\section{INTRODUCTION}

The events of September 11, 2001 changed the American aviation and aerospace scene most dramatically. One of the most affected facets of the aviation environment, that of security, has experienced - and will continue to experience-perhaps the most radical of changes, beginning with immediate intraorganizational procedural rearrangements and governmental dictates, advancing with what might prove to be the inciting moment in a new wave of regulatory and corporate reform in the signing of the Aviation and Transportation Security Act, and continuing into the foreseeable future with any number of proposed public and private actions.

General aviation will not be immune to these changes. Indeed, it is likely that general aviation security will metamorphose both in scope and importance in the near future, a transformation driven primarily by regulatory reform and industry directives. An example of a general aviation niche that could be affected by such security changes is the National Aeronautics and Space Administration's Small Aircraft Transportation System (SATS). SATS is a program involving a new generation of advanced small aircraft and supporting infrastructure designed to provide service to travelers who are underserved by current airline route networks (Tarry \& Bowen, 2001). The SATS program has been described as "an intermodal and personal transportation system" involving "point-to-point travel between smaller regional, reliever...general aviation, and other landing facilities" (Bowen \& Hansen, 2000, p. 166). Currently existing airports are envisioned as the system's backbone. New security policies and directives (destined for immediate or eventual implementation at airports of all sizes and in all parts of the United States) are certain to affect the development and manifestation of SATS-related offshoots, systems, and technologies.

The aim of this work is to discuss policy-oriented research that identifies the security issues and obstacles faced by SATS in the post-September 11 aviation environment. Especially in light of the fact that the NASA-led program has been in existence only three years, SATS will doubtless see many alterations as it comes of age in a new policy era. This article will examine a number of ideas as to how SATS might develop in an aviation security landscape far different than that in which it was conceived.

\section{SATS BACKGROUND}

According to Tarry and Bowen (2001), SATS aircraft and SATS airports are the "essential components of the Small Aircraft Transportation System"- the aircraft being compact airplanes and helicopters invested with cutting-edge technologies, the airports being modified examples taken from among the 5,400 extant public-use facilities in the United States. The aircraft will be developed by two NASA- 
facilitated partnerships known as Advanced General Aviation Transport Experiments (AGATE) and General Aviation Propulsion (GAP) (Henry, 2001). Infrastructure in the form of underused airports and airspace will be teamed with the new aircraft to, as NASA predicts, increase aviation system throughput by as much as $300 \%$ (Holmes, no date).

The SATS program exists for a number of reasons. As noted above, it will provide air service to communities underserved by presentday airline route systems. Additionally-and perhaps just as important - SATS was developed to provide air travelers relief from the extreme levels of congestion experienced at many airports in the hub-and-spoke system. Current Federal Aviation Administration (FAA) projections point to a $50 \%$ increase in demand for airport-related passenger services within the next ten years (Canavan, 2001); simultaneously, system capacity is expected to remain at or only slightly above present-day levels. This, of course, introduces gridlock as a real possibility-SATS could provide at least a partial solution thereto; indeed, NASA hopes to see SATS "cut intercity travel time by one-third in 10 years and by half in 20 years" (Bowen \& Hansen, 2000, p. 165). On a more holistic level, SATS' raison d'etre has perhaps been most clearly described in an oracular brief from NASA:

Imagine having on-demand as well as scheduled air mobility, not just to hundreds, but thousands of communities throughout the [n]ation and the world; traveling where we want, when we want, faster, safer, and with far fewer delays; having access to rural areas, no matter how remote; and having direct access to urban centers, no matter how congested (NASA Aeronautics Blueprint, 2002, p. 15).

Should this vision be realized, it would represent a large part of the future of U.S. air travel. As the FAA has reported, air travel demand could reach a level of 1.5 billion enplanements within the next twenty years (1997). At that point, finding a seat on a scheduled airline flight-even if currently planned system improvements such as very large aircraft, a free- flight operational structure, decreased separation between aircraft on takeoff and landing cycles, and runway additions were to have been successfully implemented-would be an almost impossible proposition for the average traveler (Bowen \& Hansen, 2000). Such a situation could be avoided if travelers were given another transportation option. SATS is intended to be that option.

\section{METHODOLOGICAL APPROACH}

In order to realize the most effective manifestation of results possible, this research has employed the methodological framework of meta-analysis as its primary research tool. Developed by Gene V. Glass in the mid-1970s, meta-analysis has been defined as "an approach toward summarizing the results of individual experiments... an attempt to integrate a wide and diverse body of information about a particular phenomenon" (Salkind, 1999, p. 199). Metaanalytical approaches have been shown to be effective at summarizing relationships and establishing (via aggregate analysis) other relationships (Rosenthal, 1991). (Procedurally speaking, meta-analysis can vary in form; for example, in one well-known case, it is broken down into a multi-step process [Lipsey \& Wilson, 2001].) In other words, meta-analysis is useful for synthesizing inputs from large numbers of sources while simultaneouslythrough the very act of that synthesisuncovering new avenues. Today, meta-analysis is well regarded within the ranks of the behavioral, health, and social sciences; since its genesis, it has been used in thousands of research projects (Lipsey \& Wilson, 2001). As the body of this paper took shape, the elements of meta-analysis that proved to be most often utilized were (as termed by Rosenthal) "retrieving and assessing research results" and "comparing and combining research results" (1991, pp. 36, 59).

Additionally, methods proposed by Bowen and $\mathrm{Lu}$ (2002) in their policy research construct paper have been applied to this effort. Their proposed research framework, which attempts to bridge the gap between the employment of policy analysis and policy evaluation, proves to be especially productive in the way it seeks to link input from all 
components and interests in a given policy research situation (Bowen and $\mathrm{Lu}, 2002$ ). The flowchart (see Figure 1) provides a visual study of the construct.

The construct comprises a three-phase, nine-step process, the latter comprising 1) identification of the problem, 2) identification of the issue, 3) acquisition of data, 4) analysis of policy, 5) analysis of findings, 6) evaluation of policy changes, 7) recommendation of policy changes, 8) consideration of policy reanalysis, and 9) generation/mandating of new policy (Bowen and $\mathrm{Lu}, 2002$ ). As research for this paper was conducted, focusing on steps three through six became a productive heuristic.

From an overall perspective, metaanalysis was intermeshed with the policy research construct in the form of a tool to operationalize the data acquisition process, which itself provided the results for steps four through seven. Put another way, meta-analysis was seen from the beginning of this effort as playing the part of the "tools" in Figure 1.

Furthermore, the policy research construct would be well suited to aiding future SATS-related research, especially in light of the fact that its methodological framework serves to connect all the major entities that would be party to the policy change or implementation under consideration. If applied to future SATS/general aviation security policy research, the construct would effectively synthesize the inputs of all the pertinent players on local, regional, and national levels, thereby providing a better-integrated view of the security milieu.

Several common lines of policy issues emerge in the application of the two aforementioned approaches. The backgrounds of these issues are introduced and their imports discussed in the sections that follow.

\section{THE SECURITY MILIEU: PRE- SEPTEMBER 11}

Prior to the terrorist attacks of September 11, the state of aviation security in the United States was one of business as usualbut not without some posturing for the future. Policymakers did discuss security concerns and take certain actions on various issues. These efforts notwithstanding, the status quo seemed to reign as the new millennium beckoned. Federal regulation of aviation security stemmed largely from Federal Aviation Regulation (FAR) Part 107. Titled "Airport Security," it came into being in the late 1970s and served to carry out FAA designs for modern-day airport security. More specifically, Part 107 was destined for airports which "regularly serv[e] scheduled passenger operations" (FAA, 2002). Subparts of the FAR covered virtually every conceivable angle-from inspection to coordination, tenant security to access control systems, law enforcement issues to public advisories - of the security environment.

As the 1980s gave way to the ' 90 s, Washington became concerned that the requirements of Part 107 would soon become insufficient in the face of new terrorist threats. After the loss of TWA Flight 800 in early 1996, a number of high-ranking government officials conducted inquires and studies concerning possible avenues for future aviation security measures (Jane's Airport Review, 2001). One prominent example of this reevaluation effort was an executive report on the state of domestic aviation security conducted in September 1996 by then-Vice President Al Gore; his White House Commission on Aviation Safety and Security produced a document titled "Initial Report to President Clinton" (White House Commission, 1996). Building on its genesis as a response to a presidential request for information on the deployment of new explosive-detection technologies, the report quickly broadened in scope to include a discussion of more generalized airport security topics and an examination of governmentindustry relationships.

The so-called "Gore Report" propounded both positive and negative trends in domestic aviation security. The report speaks of the need for improvements to a national aviation security system whose policies and procedures were based on 1970s-era analyses and events (White House Commission, 1996). In what is possibly the most insightful passage regarding the future of aviation security in light of what was then the Part 107 status quo, the commission reported thus:

The FBI, CIA, and other intelligence sources have been warning that the threat of terrorism is 
changing in two important ways. First, it is no longer just an overseas threat from foreign terrorists. People and places in the USA have joined the list of targets, and Americans have joined the ranks of terrorists...The second change is that in addition to well-known, established terrorist groups, it is becoming more common to find terrorists working alone or in ad-hoc groups (White House Commission, 1996, p. 1).

In the end, the commission's report spawned relatively little in the way of actual policy implementation despite its recommendation of some fifty-seven changes to U.S. aviation (Jane's Airport Review, 2001). Some commentators criticized the report's failure to address in detail the costs versus the benefits of the proposed changes; many predicted a number of the security-related problems that are now faced today in areas such as bag-matching and other procedures (Hahn, 1997; Barnett, Shumsky, Hansen, Odoni, \& Gosling, 2001). Nonetheless, some of the Gore Commission's recommendations eventually became established practices - for example, when (in January 2001) the FAA mandated the certification of security screening companies (M. M. Schaaf, personal communication, March 11, 2002).

The FAA modified the situation somewhat in the months immediately preceding the terrorist attacks. In April 2001, it released "A Commitment to Security: Federal Aviation Administration Civil Aviation Security Plan 2001-2004," a report which then-Associate Administrator for Civil Aviation Security Michael A. Canavan said would "...be [the FAA's] guide over the next few years as we work to enhance the security of the national aerospace system." The report begins with the mission statement ("Ensure and promote a secure and safe civil aviation system") and vision ("Recognized as the world leader in civil aviation security-identifying and countering aviation-related threats to U.S. citizens worldwide") of the Office of Civil Aviation Security (ACS); the balance of the report details the ACS' values, guiding principles, strategic goals and plans, and desired outcomes (Canavan, 2001). The plan was to serve as a blueprint (although it did not specifically dictate any changes to existing FARs) for the early years of a new century of civil aviation.

Despite the considerable authority of and clear exhortations emanating from the Civil Aviation Security Plan and the Gore Report, few things changed in the security environment. The airlines continued to be responsible for security provisions, and the third-party providers upon which they continued to rely became the targets of much criticism regarding the pay scales and training levels of their employees (Jane's Airport Review, 2001). Slipshod performance at airport security checkpoints across the country had seemingly become the norm.

\section{POST-SEPTEMBER 11 EVENTS AND CHANGES}

Indeed, September 11, 2001 proved to be a turning point for myriad components of the aviation industry. The terrorist hijackings of four U.S. airliners and the inconceivable events that followed set off a frisson within domestic civil aviation circles; aircraft in flight were rerouted, flights cancelled, and passengers stranded nationwide. Within hours of the attacks, some 4,500 flights that were in or coming near U.S. airspace were grounded, and 400 airports closed (Karber, 2002). The FAA then took the unprecedented step of shutting down the national airspace system for three days, effectively emptying the skies and bringing most long-distance travel to a halt. As authorities slowly allowed regularly scheduled service to resume in the closing weeks of September, it was obvious that immediate, sweeping changes were occurring. Besides the inevitable layoffs, closures, and suspensions experienced by air carriers, security procedures and systems were being altered at commercial service and general aviation airports to reflect the seriousness of a new, unprecedented threat.

Where general aviation security was concerned, the aviation-oversight agencies of the federal government reacted in especially strong fashion. The aforementioned three-day airspace system shutdown had a huge effect on general aviation; just as it was with their airline counterparts, small-aircraft pilots found themselves grounded, and as blanket no-flight restrictions were lifted in the weeks following September 11, several general-use airports in the 
northeast received FAA directives demanding that they stay closed (EAA News, 2002, January 18). November brought the signing into law of the Aviation and Transportation Security Act, the provisions of which mainly centered upon the airline industry; nevertheless, this legislative turn of events was seen by some observers as a dark omen for general aviation. As the year drew to a close, the federal government seemed to falter as it attempted to establish at least a temporary operational security structure in the tempestuous aftermath of the attacks.

Unfortunately, the outset of 2002 would bring even worse news for general aviation. On January 5, a 15-year-old student pilot crashed a Cessna 172 into the side of a Tampa, Florida office building, mimicking the attacks on the World Trade Center (Rosenberg, Waddell \& Smalley, 2002). Soon thereafter, U.S. Senator Herb Kohl (D-WI) asserted that general aviation was a "ticking time bomb," an open door for further acts of terrorism (Boyer, 2002, p. 4). Subsequently, grassroots organizations like the Aircraft Owners and Pilots Association (AOPA) mobilized, defending general aviation in the face of the ensuing maelstrom, with president Phil Boyer appearing on several major television news and talk shows and writing a number of opinion pieces cautioning against public overreaction (Active AOPA, 2002). Similarly, other lobbying organizations (e.g., the National Air Transportation Association) took pains to fend off near-constant criticism (Coyne, 2002).

Perhaps the most forcible legislative response to the attacks was the creation of an entirely new governmental oversight entity, the Transportation Security Administration (TSA). The TSA was established via the aforementioned Aviation and Transportation Security Act, which was passed on November 16, 2001, and signed into law by President Bush three days later (Carol, 2001; Croft, 2001). This new federal arm - under the umbrella of the Department of Transportation-was to be entirely dedicated to ensuring the security of all modes of transportation, not just that of air transport (U.S. House of Representatives, 2001). Deputy Secretary of Transportation Michael Jackson, in a statement made before the Senate Commerce, Science and Transportation Committee last February, described the TSA as follows:

... [it is] foremost a security agency. We will use all the tools at our disposalintelligence, regulation, enforcement, inspection, screening and education of carriers, passengers, and shippers...[this] entails consultation and participation by many outside groups-airlines, airport executives, labor unions, screening companies, airport vendors, airplane and security equipment manufacturers, trade associations, and experts" (2002, p. 3).

Despite still being in its infancy, the TSA can already be seen as a large, influential organization. An FAA official has observed that it is "the largest federal agency formed since World War II" (S. Brown, personal communication, April 16, 2002). The administration was appropriated a budget of $\$ 1.3$ billion for its first year of operation (Bond, 2002; Bush signs, 2002). Going forward, the TSA will likely "twin" with the FAA where general-aviation regulatory issues are concerned; it received a jump-start of sorts in this relationship through language in the Aviation and Transportation Security Act that mandated the implementation of a security program for charter-service operators possessing aircraft with maximum certificated takeoff weights of or more than 12,500 pounds (Carol, 2001). Another early mandate dictated that all TSAsupervised airports must have electronic baggage scanning systems installed by December 31, 2002.

The TSA has come under intense scrutiny during its first months of operation. Missed deadlines, delayed tests, and myriad passenger screening faux pas sparked public outcries and attracted unwanted media attention (Morrison, 2002, July 1). Interest groups and lobbying organizations criticized TSA demands as being unrealistic and lacking in forethought (e.g., the National Air Transportation Association's brickbats regarding the administration's so-called "Twelve-Five Rule") (New TSA, 2002). Amidst this atmosphere of uncertainty and controversy, administration head John Magaw resigned from his position after less than six months on the job (Johnson \& Hager, 2002, July 18). 
In any case, it would appear that the future of general aviation security oversight has its avatar in the TSA; it simply remains to be seen as to just how much influence this new governmental agency will exert on those entities it is designed to protect.

\section{RESULTING SATS IMPLICATIONS IN A POST-9/11 SECURITY ENVIRONMENT}

Perhaps chief among the security-related concerns faced by SATS planners in the postSeptember 11 environment is the ever-changing legislative/regulatory landscape. The current state of security at general-use airports is one thing, but the future state of security at these same airports is quite another; it can only be guessed at. What kinds of security burdens will, perforce, be placed on pilots of SATS aircraft? Will these vitiate the mobility-enhancing aspects of the SATS concept and thereby defeat its very purpose of enhancing air service to remote and underserved communities? Might federal or state regulatory authorities see a SATS aircraft as having the same potential for terrorist-related misuse as a Cessna 172? Will SATS operators be forced to foot the bill for new security mandates, much as today's air travelers must? One can only speculate as to the answers to these questions.

An example of the security issues SATS operators might face can be extrapolated from the recent passage of a bill in the South Dakota legislature that makes provisions for state-issued photo identification cards for pilots (Lowdermilk, 2002). SATS operators could, similarly, be required to be in possession of some sort of "driver's license" whenever at the controls. Another possibility exists in the form of background checks: at the beginning of 2002, bills were introduced in the state legislatures of Connecticut, Idaho, Maryland, Michigan, New Jersey, New York, Oklahoma, South Carolina, and Virginia to mandate background checks for all flight students (Lowdermilk, 2002). Would a SATS owner/operator face a like mandate?

Again continuing to extrapolate and visualize, one could posit the idea that, what with the rising support for an expansion of federally mandated baggage checks, a preflight examination of all baggage by a federal employee might very well become a part of a given day of travel for a SATS operator (M. M. Schaaf, personal communication, March 11, 2002). Passenger identification checks - also performed by airport security personnel - could be a further possibility. And, since design parameters for SATS aircraft include unprecedented levels of user-friendliness, ease of theft is yet another concern.

Regulatory entities and overseers of general aviation security have been left to make sense of a complicated situation. Nebraska Department of Aeronautics Director Kent Penney, for example, has asserted that though the ends are simple and clearly defined, the means are not; the goal is to "keep [potential criminals] off the airport, out of airplanes, and out of the cockpit," but the methods and capital required to do so effectively at every airport are difficult to come by (K. Penney, personal communication, April 4, 2002). According to Penney, efforts thus far have been focused on awareness. Nebraska, for example, has recently established a neighborhood- watch type program (in which pilots and airport personnel keep a close eye on daily operations) and introduced a new initiative aimed at greater cooperation between industry and local law enforcement. These could, of course, ultimately be but an overture in a long, convoluted security metamorphosis; with this is mind, Penney has stated that progress in the SATS program "is going to have to be evolutionary, possibly even incremental," in nature (personal communication, April 4, 2002).

It would appear as though this new, uncharted security territory will be difficult for SATS to navigate. New rules and regulations, the advent of a governmental agency of unprecedented scope and power, and public concern make up just a few of the obstacles ahead. Adding to these hurdles is the fact that the program itself has already survived at least one public attempt on its existence, a Transportation Safety Board committee having recommended in April 2002 that SATS be eliminated from NASA's cache of research programs and its funding be used for other purposes (Kim, 2002, April 26).

Despite the odds, SATS could experience a reversal of fortune in the foreseeable future. 
One could make a sound argument for SATS in the post-9/11 security environment grounded in the fact that its components are designed to relieve congestion at existing and future hub airports by bypassing them entirely. Indeed, as the NASA Aeronautics Blueprint has noted, "Since deregulation... air travel has tripled while the air transportation support infrastructure has remained relatively unchanged" $(2002$, p. 6); a number of possible SATS advantages could be seen to emerge in such a congested environment. What's more, tangible progress toward the ultimate realization of the SATS concept is already occurring, with new, SATS-precursor aircraft such as Eclipse Aviation's six-seat, jetpowered Eclipse 500 approaching production status (Tarry \& Bowen, 2001).

Assuming that changes in the general aviation security regulatory environment are kept to a minimum, a future SATS owner, operator, or passenger could see edges (over commercial airline passengers) in areas such as choice, time, and convenience. A good operational analogy to SATS can be seen in present-day charter operations, in which persons or corporations contract with a flight-service provider on an exclusive, personally scheduled, trip-by-trip basis. Charters provide a unique "go-anywhere-at-any-time" product that the scheduled airlines cannot match. Similarly, SATS aircraft will allow their operators the freedom of being able to choose where they want to go, when they want to go, and what route to take (and all this, of course, at a cost far smaller than that which a typical charter operation would charge) (M. M. Schaaf, personal communication, March 11, 2002). Potential airline passengers would choose the SATS option, recognizing it to be a viable alternative to the inconveniences of scheduled hub-and-spoke travel. Therefore, with SATS aircraft taking vast numbers of passengers out of the overburdened airline route system, capacityrelated security problems would be effectively addressed. What's more, should the current state of affairs in security screening continuei.e., intrusive, time-consuming, and, in some cases, offensive screening procedures, some of which have been described as "overzealous," "irrelevant," and, indeed, "the stuff of late-night comedy on TV"-SATS could become even more attractive to the air-traveling public (Flint, 2002; Gwinn, 2002). Additionally, were the SATS system to come online in such a situation and prove itself as a viable, safe, efficient form of transportation, it could serve to brighten the soiled image of general aviation as a whole. (Put another way, a successful overture on the part of the SATS program could be an apt response to the recent statement of the AOPA's Boyer that "[general aviation] and its real role in the national air transportation system are not understood by the general public and...government officials" [Spence, 2002, p. 29].)

\section{POLICY RESEARCH ISSUES AND QUESTIONS: A META-ANALYTIC OUTCOME}

Ultimately, the issues brought forward by this work are perhaps best summarized in questions. Will the government and the public recognize the security- and convenience-enhancing possibilities inherent in SATS? Will SATS prove to be a viable alternative to regularly scheduled air service as we know it today, or will the current and near-future aviation security milieu and its attendant issues and demands derail the entire SATS program? What are the implications of the growth process of the TSA for general aviation security? How will SATS owners/operators relate to and interact with the general aviation security environment of tomorrow?

Recommended areas for future investigation are numerous. Primary among these would be TSA-related possibilities involving general aviation; since general aviation is the existing category of flight into which SATS would most probably fit, the TSA's general aviation-related opinions and mandates would be important to research as the administration grows in size and scope. Another area worthy of consideration is the perception of general aviation and SATS on the part of the media and the public-perception being a key issue in anything related to aviation. Additionally, as more information becomes available on the specifics of SATS aircraft and infrastructure, the practicalities of SATS operations in future security environments could be investigated. Yet another area deserving 
thought is that of state-level issues concerning general aviation and SATS; specifically, how state officials might regard SATS operations at local airports. Finally, it remains an open question which of the major general-aviation lobbying groups (e.g., the Aircraft Owners and Pilots Association, the National Air Transportation Association, et al.) might best champion the cause of SATS as the program nears its implementation stage.

\section{CONCLUSION}

The number and scope of uncertainties surrounding SATS and the new U.S. aviation security climate are sufficient to warrant further research. Indeed, it is not unreasonable to assert that the SATS program and the new aviation security environment are equally inchoate, that there are more questions than answers, that there are applicable issues and problems and ideas not yet even in existence. Conducting further research is the proper response to this situation.

The Policy Research Construct proposed by Bowen and $\mathrm{Lu}$ (discussed elsewhere in this paper) is well suited for application to such research. By employing the construct, researchers would be able to further and more completely synthesize feedback and data from all players in the general aviation security situation, thereby creating a solid foundation from which to propound policy examination or revision.

The unknown abounds in the general aviation security environment of the early $21^{\text {st }}$ century. Problems, both real and envisioned, have already arisen, and will doubtless continue to do so, challenging industry, government, and the flying public alike. That the Small Aircraft Transportation System would not be immune to the unprecedented changes and general turbulence caused by the terrorist attacks of last September was a foregone conclusionhowever, where this new, unforeseen era of aviation security will lead this potentially revolutionary transportation method is anything but. 
Figure 1

Flowchart for the Aviation Policy Research Construct

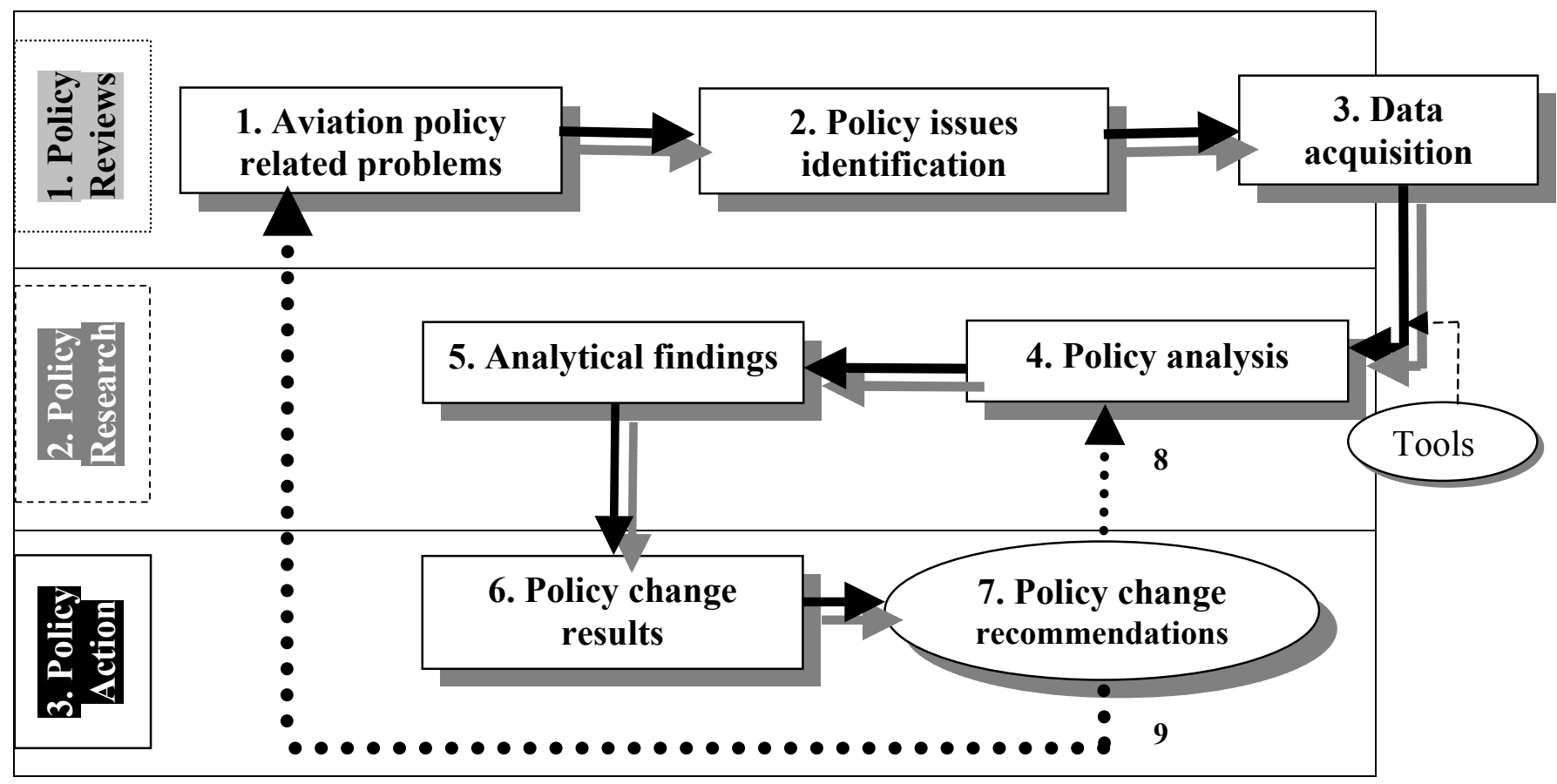




\section{REFERENCES}

Active AOPA defense followed crash. (2002, March). AOPA Pilot, 45, 4.

Airfield and aircraft security in the wake of the terrorist attacks. (n.d.) Retrieved January 29, 2002, from http://www.faa.gov/asw/asw600/AASECURITY.doc.

Barnett, A., Shumsky, R., Hansen, M., Odoni, A., \& Gosling, G. (2001). Safe at home? An experiment in domestic airline security. Operations Research, 49(2), 181-195.

Bond, D. (2002, February 11). Security claims most of aviation's increase. Aviation Week and Space Technology, 156, 36.

Bowen, B. D., \& Hansen, F. D. (2000). Implementing a national Small Aircraft Transportation System: A public infrastructure challenge. Public Works Management and Policy, 5, 160-169.

Bowen, B. D., \& Lu, C. (2002). Policy research construct: A research proposal for a comprehensive aviation policy making. Unpublished manuscript, University of Nebraska at Omaha.

Boyer, P. (2001, December 30). Major change unnecessary [Electronic version]. USA TODAY. Retrieved January 29, 2002, from http://www.usatoday.com/news/comment/2001-12-31ncoppf.htm

Boyer, P. (2002, March). TFRs. AOPA Pilot, 45, 4.

Bush signs off on $\$ 13.3$ billion FAA budget for FY 2002. (2002, January 18). General Aviation News, p. 24.

Canavan, M. A. (2001). A commitment to security: Federal Aviation Administration civil aviation security strategic plan 2001-2004. Retrieved January 21, 2002, from $\mathrm{http} / / /$ cas.faa.gov/strategicplan.doc

Carol, B. (2001, November 22). Aviation security sweeps the country. AvWeb News Wire. Retrieved February 27, 2002, from http://www.avweb.com/newswire/news0147b.html

Coyne, J. K. (2002, April). When fear isn't fair. NATA News, 32, 2, 6.

Croft, J. (2001, November 19). Air security bill clears lawmakers' logjam. Aviation Week and Space Technology, 155, 46.

FAA working with airport managers to open three GA fields closed since Sept. 11. (2002, January 18). EAA News. Retrieved from http://www.eaa.org/communications/ eaanews/020118 faa.html

Federal action urged. (2001, November). Jane's Airport Review, 13, 24.

Federal Aviation Administration. (2001). Federal Aviation Regulation Part 107-Airport Security. Retrieved March 7, 2002, from http://www.acmp.com/data/fars/far-107.txt

Flint, P. (2002, March). Stop the madness. Air Transport World, 39, 7.

Gwinn, D. (2002, January). Perspective: Should you be offended? Plane \& Pilot, 38, 24-25. 
Hahn, R. W. (1997). The economics of airline safety and security: An analysis of the White House Commission's recommendations. Harvard Journal of Law \& Public Policy, 20(3), 791-828.

Henry, K. (2001). NASA selects teams for Small Aircraft Transportation System research and technology development program. Retrieved January 29, 2002, from http://sats.erau.edu/News/NASA_News_Release_072501.html

Holmes, B. J. (n.d.) National General Aviation Roadmap for a Small Aircraft Transportation System (SATS). Retrieved June 22, 2002, from the University of Nebraska at Omaha, Aviation Institute/Small Aircraft Transportation System Web site: http://www. unomaha.edu/ unoai/sats/

Johnson, A., \& Hager, R. (2002, July 18). Magaw forced out as security chief. Retrieved July 18, 2002, from http://www.msnbc.com/news/782337.asp?0cm=c10.

Karber, P. (2002). Re-constructing global aviation in an era of the civil aircraft as a weapon of destruction. Harvard Journal of Law \& Public Policy, 25(2), 781-814.

Kim, A. (2002, April 26). Research group declares NASA's small airplane project implausible [Electronic version]. Aviation Week and Space Technology. Retrieved June 23, 2002, from $\mathrm{http} / /$ www.aviationnow.com/avnow/autonomy_samples/autonomysuggest/ autosuggest.jsp?docid $=16369 \&$ url=http $\% 3 \mathrm{~A} \% 2 \mathrm{~F} \% 2 \mathrm{Fwww}$.aviationnow.com\%2Favnow\%2Fnew s\%2Fchannel_busav.jsp\%3Fview\%3Dstory\%26id\%3Dnews\%2Fbsats0426.xml

Lipsey, M. W., \& Wilson, D. B. (2001). Practical meta-analysis. Thousand Oaks, CA: Sage.

Lowdermilk, A. M. (2002, February 26). Security_FYI. Message posted to http://www.aopa.org/asn

Morrison, B. (2002, July 1). Screeners miss even obvious items. USA Today, p. 4A.

National Aeronautics and Space Administration. (2002). NASA aeronautics blueprint. Retrieved February 18, 2002, from http://www.aerospace.nasa.gov/ aero_blueprint/index.html

New TSA security rule flawed. (2002, May). NATA News, 32, 6.

Rosenberg, D., Waddell, L., \& Smalley, S. (2002, January 21). A troubled teenager's tragic final flight plan. Newsweek, 139, 40-41.

Rosenthal, R. (1991). Meta-analytic procedures for social research (Rev. ed.) Newbury Park, CA: Sage.

Salkind, N. J. (1999). Exploring research. ( $4^{\text {th }}$ ed.). Upper Saddle River, NJ: Prentice Hall.

Spence, C. (2002, March 15). Clenched fist. GA News, 54, 25-30.

Statement of Michael Jackson, Deputy Secretary of Transportation, and John Magaw, Under Secretary of Transportation for Security, before the Commerce, Science and Transportation Committee, United States Senate, $107^{\text {th }}$ Cong., 1 (2002) (testimony of Michael Jackson).

Tarry, S. E., \& Bowen, B. D. (2001). Optimizing airspace system capacity through a small aircraft transportation system: An analysis of economic and operational considerations. Journal of Air Transportation World Wide, 6(1), 65-76. 
United States House of Representatives. (2001, November 16) The Aviation and Transportation and Security Act. Retrieved January 31, 2002, from http://www.nbaa.org/@@2AnvCTDiJwEJ/ gov/107-296 Security.pdf

White House Commission on Aviation Safety and Security. (1996, September 9). Initial report to President Clinton. Washington, DC: U.S. Government Printing Office.

\begin{abstract}
AUTHOR NOTE
This research was supported by funding from the National Aeronautics and Space Administration's Experimental Program to Stimulate Competitive Research (EPSCoR).

Correspondence concerning this article should be addressed to Brent D. Bowen, Aviation Institute, University of Nebraska at Omaha, 6001 Dodge Street, Omaha, Nebraska 68182-0508.
\end{abstract}

